\title{
District Heating in the UK: Prospects for a Third National Programme
}

\author{
David JCHawkey
}

The UK has seen periodic attempts to develop large district heating (DH) networks to make use of residual heat from industry and power generation. Under concerns about climate change and energy security, $\mathrm{DH}$ has recently re-emerged in policy visions for future heat systems with small decentralised combined heat and power (CHP) generators playing a key role in the establishment of such networks. This paper draws on Stewart Russell's accounts of earlier DH programmes, asking to what extent the reasons he concluded $\mathrm{CHP}$ and $\mathrm{DH}$ were systematically excluded continue to marginalise the technologies. In spite of governance changes which ostensibly open new opportunities for experimentation, key structural issues challenge the development of decentralised energy, particularly the alignment of the electricity sector to a centralised system and the dependency of local governments with limited capacity on central government. The reluctance of central government to engage in system planning and the failure to integrate policies related to energy production and energy consumption limit the effectiveness of support for $\mathrm{DH}$.

Keywords: district heating, combined heat and power, energy policy

\section{Introduction}

On page 78 of its 2013 policy paper, The Future of Heating: Meeting the challenge, the UK Department of Energy and Climate Change (DECC) illustrates its strategic framework for low carbon heat in buildings in a figure showing a "pincer movement" involving different energy networks. New district heating (DH) networks would be established in dense urban areas, in time expanding outwards to lower density suburbs. Electricity networks would be upgraded to support building-scale electric heat pumps in rural areas, with reinforcement progressively extending to higher density areas. The currently ubiquitous gas network (which serves around $80 \%$ of building heat demand) would eventually be scaled back dramatically (DECC, 2013).

The figure, as a summary of the Government's proposed strategy, is remarkable for a number of reasons. First, the scale of the change envisaged is unprecedented: while there are countries where district heating and/or electric heating are ubiquitous (particularly in Scandinavia) there is no precedent for a transition away from widespread network gas heating (International Energy Agency, 2009). Second, the "pincer movement" 
is presented as a shift in thinking about heating, away from an emphasis on the technologies connected to networks, to consideration of system wide configurations of network infrastructure. Third, the strategy is clear that decisions between heating technologies and infrastructure will be driven by informed consumers, and not by government-led planning (of the sort which underpinned development of most widespread energy distribution networks in the past) (Graham \& Marvin, 2001; Grohnheit \& Gram Mortensen, 2003). And fourthly, because the UK Government has twice before tried to establish major programmes of district heating, neither of which succeeded.

The Ministerial foreword to DECC's Heat Strategy states, "We have [...] inherited a big hole where there should be policy for finding alternatives to fossil fuel for the supply of heat," (DECC, 2013: 1). To the extent that this "big hole" relates to district heating, Stewart Russell's pioneering work on the social shaping of technology (Russell, 1993, 1994, 1996), which sought to explain the neglect of combined heat and power (CHP) and district heating (DH), provides a valuable basis on which to understand the roots of this inheritance. Russell's account rejected the notion that technological development and deployment were driven by an internal logic of improvement, and sought instead to reveal "the complex interaction of economic, political and social forces that shape development and adoption of technologies in particular forms" (Russell, 1993: 50).

Russell argued that the neglect of CHP/ $\mathrm{DH}$ in spite of attempts to introduce it was systematic (in the sense of being characteristic of a social formation) rather than accidental (in the sense that a different outcome could have been realised without significant changes to the energy sector or wider society). This paper examines the prospects for $\mathrm{DH}$ to become more widely used in the UK as envisaged in DECC's (2013) heat strategy, drawing on Russell's historical analysis to ask to what extent the forces he identified as systematically marginalising $\mathrm{CHP}$ and $\mathrm{DH}$ have parallels today, and whether emerging policy approaches address these issues in an effective way.

The paper is organised as follows. The next section introduces the concepts used in the paper, drawing out central social shaping of technology themes in Russell's writing on $\mathrm{CHP} / \mathrm{DH}$ in the UK. This section frames the later discussion by drawing on energy policy and governance literatures to present some of the contemporary contextual aspects of the UK relevant to the investigation. After that I describe the empirical material used in the two sections that follow, which explore issues confronting the development of $\mathrm{DH}$ networks and CHP systems providing heat to them respectively. The final section concludes.

\section{DH, CHP and the Political Economy of the UK}

\section{History of CHP and DH Programmes}

Although experiments with CHP and DH can be traced back to the late $19^{\text {th }}$ Century, the first significant attempt at a national $\mathrm{DH}$ programme in the UK followed the Second World War. Central government initially saw significant opportunities for rationalising energy use in a context of limited supply by coordinating the newly nationalised energy industries with the reconstruction and regeneration of British cities. However, the organisational challenges implied by widespread district heating, resistance within the nationalised electricity supply industry to operate (or accept electricity from) CHP, restrictions on the powers of local authorities and resource 
shortages affecting the housing programme contributed to the failure of these plans (Russell, 1993, 1994, 1996).

National visions of widespread cityscale DH systems were revived in the second attempted major programme, the "Lead Cities" programme, which arose in the context of concerns around resource availability prompted by the 1970 s oil crises. The programme was caught up in, and ultimately fell victim to, widespread changes in government policy which eventually led to the liberalisation and privatisation of most nationalised industries, including the energy industries. In this context, DH and CHP were seen as something of a test case for the new approach, with Government scaling back its proposed investment in favour of private capital. The shrinking number of cities included in the programme found they were unable to make schemes attractive to private investors who sought higher and shorter-term returns, and whose perceptions of investment risk were likely heightened by the Government's apparently waning commitment (Russell, 1993, 1994, 1996).

Stewart Russell's historical analysis of $\mathrm{DH}$ programmes was inherently sociotechnical, emphasising that the development of technology and social arrangements are part of the same process (Russell \& Williams, 2002b). Key STS features of Russell's account include alignment of interests around a centralised electricity system supported by co-production of that system and its social organisation, the distributed nature of change that widespread use of CHP and DH would imply, and a balance between the apparently idiosyncratic issues that held back particular schemes and the systemic issues which kept the technologies in a precarious and marginal position (c.f. Russell \& Williams, 2002b).

The twin products of CHP, heat and power, underpin the division which runs through Russell's account between the integration of the technology with the electricity system, and the development of $\mathrm{DH}$ infrastructure. Issues in the former domain focused on the centralised character of the electricity system, both in its organisational form as a national-scale state owned company and the corresponding technical configuration the industry pursued with large centralised stations and electricity cascading down through transmission networks to distribution networks to consumers. Incompatibilities between this centralised sociotechnical system and the use of CHP as a smaller scale electricity generating technology embedded in distribution networks, both in terms of a capital investment programme and in relation to network control, led to the marginalisation of the technology from the electricity supply industry under both programmes. This marginalisation took the form both of decisions within the nationalised industry not to develop its own CHP systems, and of an unsupportive (and at times actively hostile) response of the industry to other organisations feeding CHP electricity into the public system.

The latter domain, the development of $\mathrm{DH}$ infrastructure networks, was also frustrated by capacities and interests influenced by organisational structures and relationships. While some organisations (such as universities) developed heat networks to serve a small number of buildings, local authorities, in the main, were the central actors in plans for larger scale, multi-organisation heat networks (Russell, 1993). UK local authorities are limited by the ultra vires principle which prevents them from engaging in activities not expressly sanctioned from the centre (Wilson \& Game, 2002). In the post-war period, no general dispensation for local government to develop or operate $\mathrm{DH}$ networks existed. When the UK parliament 
granted individual local authorities powers, they were often restricted to fragmented areas of their city. By the second CHP/DH programme local authorities had general powers to develop heat networks, but their capacity to shape the spatial relationships between sources of, and demand for, heat was limited by constraints on their spatial planning powers. Dependence on central government was manifest during the second period in the arrangements for financing $\mathrm{DH}$ systems: initially central government support was planned, but this was withdrawn in favour of private capital which proved difficult to mobilise at a cost which systems could cover (Russell, 1996).

Russell (1993: 48) argued that the split between organisations involved in heat and power reflected not only the twin products of CHP, but also a characteristic split in energy debates in the UK between interests organised around energy production (viz. the electricity industry) and interests organised around consumption (as mediated or expressed by local authorities seeking to achieve social goals through development of heat networks). Contrasting the UK with other Western European countries where extensive $\mathrm{DH}$ systems have developed is instructive. During DH development, these countries had relatively autonomous local government, often able to coordinate heat network development with municipally operated electricity systems, other local infrastructure, and development of the built environment, particularly housing (Ericson, 2009; Grohnheit \& Gram Mortensen, 2003; Raven \& Verbong, 2007; Rutherford, 2008; Summerton, 1992).

In Russell's account, the dependence of $\mathrm{DH} / \mathrm{CHP}$ development on UK central government can be seen in the effects of its withdrawal from an active role in planning at the times of both programmes. While nationalisation of the energy industries was justified in terms of rationalising a dysfunctional sector, the UK government's plan for CHP and DH was not embedded in a strategic vision of the configuration, components or integration of the energy industries. When the electricity industry sought to establish its autonomy from central government control (indeed using CHP as a test case for this relationship), central government acquiesced, choosing rather to use the nationalised industries only expediently as a component of its Keynesian management of the economy (Russell, 1996). The explicit goal of freeing the energy industries from political control through privatisation contributed to the destabilisation and failure of the second programme.

Complementing these structural issues, Russell also described some of the mechanisms by which organisational interests were expressed and translated into action, or more commonly inaction. While a wide range of social issues motivated interest in CHP and DH (raising standards of living, cheap warmth for low income households, efficient use of resources, regeneration of local industry, local employment and regeneration of housing stock), terms of appraisal imposed on CHP/ $\mathrm{DH}$ schemes were progressively narrowed to cost benefit analyses and ultimately (in the run-up to privatisation) whether schemes could offer returns attractive to private investors (Russell, 1993). Russell argued that the 'technical' character of debate this led to did not undermine his analysis of organisational interests. Indeed, the fact that a variety of different methods and criteria for appraising $\mathrm{CHP} / \mathrm{DH}$ were deployed in these debates supports the view that judgements whether the option was 'economic' or not could not be reduced to some internal technical characteristics. Instead, Russell argued, appraisal reflected the priorities of, and constraints on, the performing institution. For example, the 
nationalised electricity company concluded that in only in a limited number of cases would DH be 'practicable and economic', ignoring its own role in weakening the financial case for $\mathrm{DH}$ by offering poor terms and low prices for electricity from CHP. The failure to consider CHP as an integral part of the UK's energy systems, instead holding it as an adjunct to a centralised system, meant schemes struggled to find a viable position in a system not designed for them. The marginal performance of the fragmented schemes which struggled to exist in this context itself became part of the marginalisation of the option, negatively shaping visions and understandings of what CHP and DH would mean in the UK, visions which were weakly articulated and not widely shared in the first place (Russell, 1993; Weber, 2003).

This presentation does not exhaust the themes and detail of Russell's account (for example, the association of CHP and DH with a range of issues and support from unusual political coalitions). However, it is these themes - the shaping of interests and capacities through organisational structures and relationships, and mechanisms by which those interests are expressed - that I focus on in exploring the contemporary prospects for CHP and $\mathrm{DH}$.

\section{Contemporary UK Energy Policy and Politics}

While Russell's account revealed striking parallels between the failure of both the CHP/DH programmes of the 1940s/50s and the 1970s/80s, they failed at different times and under different conditions. In the post-war period, industry and government coalesced around a model of centralised command-andcontrol decision making oriented to rational infrastructure development as a component of economic expansion (Helm, 2005). The second programme was caught up in the 1979 government's moves to redefine the boundaries of the state, with liberalisation and privatisation of energy an iconic example of a widespread shift in governance arrangements to the use of competitive markets (and, where such markets were not feasible, marketmimicking mechanisms) with the aim of driving up economic efficiency through lower costs and stimulation of innovation (Fudge et al., 2011; Helm, 2005).

The character of energy policy (and the corresponding industry structure) in these periods was reflective of what Russell and Williams (2002a) identified as more widespread developments in technology policy, from nationally organised infrastructure, industrial and military programmes up to the 1970 s, to policies inaugurated in the 1980s designed to create supportive conditions for a wider range of actors to innovate. Russell and Williams (2002a) detected a further shift in technology policy from the end of the 1990s towards an approach which maintains an orientation to distributed processes (indeed national governments have largely retreated from planning), while accommodating a more complex view of the development of technologies and a corresponding broadening of the sites for policy intervention.

In UK energy policy, the extent of such a shift is the subject of academic debate. Helm (2005) argues that contrary to political expectation, liberalisation did not result in de-regulation of energy, and that the enduring role of government in setting the framework for the (increased range of) actors in the energy system has become more pressing through mounting energy security and environmental problems. These pressures became so acute at the end of the 1990s that government was led to explore a wider range of policy interventions to purposively reshape UK energy systems 
(Helm, 2004, 2005). Others disagree with the contention that this represents a new 'paradigm' in energy policy, arguing that significant continuities with the 1990s exist in commitments to market and market-mimicking approaches to resource allocation (including investment decisions), technology neutrality of policy, independence of regulation and linking of growth-based indicators of prosperity with analyses of energy economics (Fudge et al., 2011; Mitchell, 2008). These authors argue these continuities render policy interventions ineffective, and marginalise visions of an energy system radically different to the current fossil fueldependent centralised system.

Shifts (to whatever extent) in energy policy are embedded in broader political and policy programmes and assumptions. Moran (2003) argues that the form in which the energy sector was reconfigured in the 1990s is part of a more general transition in UK governance (covering sectors as diverse as financial services, medicine and sport), from systems of 'club government' to systems of enforced selfregulation which Mitchell (2008) groups under the Regulatory State Paradigm (RSP). Where club government was oriented to closed networks, personal contacts, tacit understandings and autonomy of sectors from state oversight, its replacement, the RSP, is characterised by codified, juridified and institutionalised systems of regulation. An important aspect of RSP governance is an emphasis on the autonomy of multiple actors' decision making in regulated areas, on grounds that distributed actors have better access to information than a central actor. However, this emphasis sits uneasily with the state's on-going modernist ambitions, such as to radically reduce territorial greenhouse gas emissions. In combination, these features of the RSP imply complex policies and programmes which aim to shape distributed actors' decisions (for example, by altering relative prices). The demands of calibration and monitoring of these interventions has led central government to seek more information in pursuit of what Moran (2003) calls synoptic legibility. The relationship between local and central government has undergone changes in line with these broader developments, seeing an increase in the use of indicators and audit of performance alongside moves towards greater freedom of action from central control (Martin, 2011; Nutley et al., 2012).

Details of how these broad shifts in governance in the UK are manifest in the domains of local government and energy are examined in later sections of the paper. However, this high level view of governance changes in the UK sets the context for the investigation: to what extent do attempts by central government to distribute decision making in energy and local government across other actors support or impede the contemporary development of CHP and $\mathrm{DH}$ ?

\section{CHP, DH and Low Carbon Energy}

DH networks are 'source agnostic' and heat from CHP can be used in a variety of applications, so a coupling between CHP and DH is not inevitable. Indeed, the development of DH networks in Sweden included very little CHP, and much of the CHP developed in the Netherlands in the 1990s did not feed DH networks (Ericson, 2009; Hekkert et al., 2007). In the UK, DH development commonly draws on gasfired megawatt-scale CHP. Gas CHP offers desirable characteristics to DH developers and operators: as a mature technology with well established fuel supply, heat source risks are reduced. In addition, electricity prices in the UK are largely determined by gas prices and the main competitor for heat supply is gas, meaning changes in input and 
output prices for gas CHP move together, giving the technology a 'natural hedge.' The proportion of homes with central heating has increased steadily from less than a third in 1970 to over 95\% (Palmer \& Cooper, 2011). Fuel poverty measurement varies between parts of the UK, but in broad terms was at a low point of around 5\% of households in 2004 and has consistently risen to around 15\% in 2011 (Hills, 2012). CHP and DH can make heating more affordable particularly when replacing electric heating, making retrofit of $\mathrm{CHP} / \mathrm{DH}$ to alleviate fuel poverty in electrically heated high-rise dwellings a particular target for the technology (DECC, 2013).

The link between DH and CHP in what follows is, therefore, justified by this link existing in contemporary practice, though over the longer term this relationship may evolve into something different. While (unabated) fossil-fuelled CHP can achieve short-term greenhouse gas emissions reductions, it nonetheless produces $\mathrm{CO}_{2}$, and may in future be more carbon intensive than alternative forms of heat and power generation, such as renewable electricity and electric heat pumps (DECC, 2013). The role of CHP and DH in possible trajectories of decarbonisation of energy systems is, however, complicated by the possible dynamics of future energy systems including the role of $\mathrm{CHP}$ in efficient balancing of an electricity system with inflexible generation such as nuclear and renewables (Lehtonen \& Nye, 2009; Toke \& Fragaki, 2008) and the use of CHP as a bridge to lower carbon heat sources (DECC, 2013; Rotheray, 2011). Large scale DH networks could have a variety of relationships with other energy systems depending on future outcomes (in patterns of generation and resource availability) that are currently highly uncertain. Considering these relationships is beyond the scope of this paper, but is noted as one source of uncertainty and complexity confronting development of DH and CHP in the UK.

\section{Data Sources}

This paper draws on the first three years of a four year research project into the prospects for sustainable heat in cities, Heat and the City (www.heatandthecity. org.uk). The project explores the prospects for development of sustainable heat in UK cities and has gathered a range of original empirical material through surveys, interviews, workshops and observation at meetings. This dataset concerns household experiences with $\mathrm{DH}$, the organisation, development and financing of local $\mathrm{DH}$ initiatives, and policy making at local authority, Scottish Government and UK Government levels. In this paper I draw on a subset of this empirical material as it relates to the development of heat network infrastructure (next section) and the relationship between $\mathrm{CHP}$ and $\mathrm{DH}$ with the incumbent energy system (subsequent section). Original data is combined with analysis of policy documents, practitioner guides and research reports, and relevant academic literature as indicated in the text.

The material used in the section on the development of $\mathrm{DH}$ networks focuses primarily on the role of local government. The perspectives of local authority officers on the challenges of developing heat networks are drawn from 49 interviews with officers across 5 city case studies, along with a series of 4 workshops, organised as part of Heat and the City, with members of a network of 65 local authorities and 12 housing associations actively engaged in developing district energy initiatives. This material is combined with observations from academic literature on local government and documentary analysis of UK policies concerning the powers of local authorities and support for $\mathrm{DH}$, to situate 
the reported immediate concerns of these individuals in a broader context of local governance.

The exploration, in the subsequent section, of the integration of $\mathrm{CHP} / \mathrm{DH}$ with the incumbent energy system is guided by challenges reported by project developers, consultants and industry, and draws parallels between these and issues Russell highlighted in his historical account. This material is combined with interview data and engagement at meetings and workshops with government energy policy makers. Again, rather than take the perspective of these individuals as objective sources of information, this primary data is supplemented by analysis of the evolution of UK energy policy through documentary analysis and relevant issues identified in the literature on UK energy governance.

\section{Contemporary Development of Heat Networks in the UK}

Local government has historically played a central role in attempts to develop DH networks, both in the UK and elsewhere (Russell, 1993; Ericson, 2009; Grohnheit \& Gram Mortensen, 2003). The breadth of its estate (including housing development) means it can anchor local heat networks, its role in spatial planning and building control enables it (in principle) to strategically coordinate infrastructure development, it is able to broker relationships between organisations with local presence, and its potential to make long term investment is underpinned by its commitment to the locality, low borrowing costs and its role in securing local social objectives. While other organisations can (and do) develop heat networks (particularly campus-based organisations such as universities and hospital complexes, or social landlords), local government nonetheless is looked to by both policy-makers and practitioners in the UK as playing a crucial role in the possibility for city-wide DH systems able to achieve greater economies of scale (International Energy Agency, 2005).

\section{Fragmented Local Governance}

Recent UK reforms to relationships between central (and devolved) government and local government ostensibly empower local authorities to act innovatively (Martin, 2011). The ultra vires principal has been relaxed somewhat by new powers of "wellbeing" (introduced in 2000) which allow local authorities to undertake activities judged to improve the social, economic or environmental wellbeing of their areas. The financial liability local authorities can incur is no longer capped by central government. Instead borrowing is regulated by a set of rules (the Prudential Code) administered by an independent professional institute (the Chartered Institute of Public Finance and Accountancy).

However, limited capacities of local government to develop DH networks, and the dependence of local authorities on support from central government remain striking features of UK DH development. While borrowing powers have been extended, financial autonomy from central government is limited in comparison with other European countries, with a relatively low proportion of local government funding coming from local taxes and fees (Wilson \& Game, 2002). The introduction of the wellbeing powers was accompanied by new forms of performance management structured around performance indicators and ring-fencing of central government grants to specific local activities, which led many local government departments to be more responsive to their central government equivalent than their local counterparts (Leach \& Percy-Smith, 2001; Wilson \& Game, 2002). 
A parallel trend in local governance in the UK has been the fragmentation of local service delivery. In pursuit of performance improvement through competition, various powers and responsibilities have been transferred from local government to other providers. For example, the 1988 Housing Act removed local government's monopoly on state-subsidised social housing, allowing numerous Housing Associations to compete for this function, limiting local government's capacity to coordinate social housing development (Wilson \& Game, 2002). In addition local authorities, under obligations to secure "best value", have been increasingly tendered services for which they have statutory responsibility (such as refuse collection and ground maintenance) to commercial providers (Leach \& PercySmith, 2001).

The consequences of local fragmentation and entrenched central control for local government's capacity and willingness to develop DH systems are various. Local government activities are oriented towards exemplifying good practice (e.g. reducing its own estate's carbon footprint) and enabling others to act, rather than direct provision of services (Bulkeley \& Kern, 2006). Our case-study research across different local authorities indicates an uncomfortable fit between $\mathrm{DH}$ and organisational structures, with different departments taking the lead on heat networks in different authorities (for example, housing, regeneration or environmental departments). Departmental fragmentation can frustrate attempts to develop schemes: for example in one case we have examined a lack of cooperation among neighbouring departments has undermined implementation of a pilot scheme, particularly its designed use of existing revenue and accounting systems to manage customer billing.
The capacity within local government to develop technically and financially viable energy systems is limited not only by their lack of experience with energy (having had the power to operate gas and electricity systems removed under the nationalisations in the 1940s), but also by the orientation of in-house skills to managing relationships with external service providers. Where local government has developed DH systems, this has often relied on costly consultancy services, and where officers lack technical knowledge to adequately specify consultancy requirements the quality of work delivered is variable: for example, in one case we have researched in depth, an initial feasibility study indicated the proposed scheme would require under $£ 10 \mathrm{~m}$ investment, while a second study doubled the capital cost, reduced the payback period by over a year and indicated the scheme's internal rate of return would be twice that initially estimated. Furthermore, local government officers in district energy workshops have raised concerns about the impartiality of advice (which is cheaper from companies able to also construct DH systems) and the outsourcing of knowledge development (see also King \& Shaw, 2010). Those local authorities which have developed DH systems follow different routes (Hawkey et al., 2013) but a common theme emerging from interviews and workshops with local authority officers is that project success relies on the persistence of a small number of dedicated individuals, often just one or two, whose struggles to coordinate resources within their organisation are neatly captured in the epithets they apply to themselves, such as "sheepdog," "wilful individual," or "lone nutter."

Thus while local government potentially plays important roles in the development of strategic, city-wide heat networks, their limited capacity coupled with fragmented 
internal structure and dispersal of service delivery across numerous other organisations often limits the scope of planned systems. While enthusiastic local authority officers participating in district energy workshops try to "think big but start small" (Lovell et al., 2011) the challenges of designing and funding future-proofed systems (for example, with oversized pipework to ensure capacity for future connections) coupled with uncertainty in whether additional heat load will be available in future mean implementation of a strategic approach is rare. DECC has recently created a Heat Networks Delivery Unit, one function of which is to help local authorities navigate the development of schemes, particularly supporting them in negotiation with the private sector for consultancy services (DECC, 2013). Whether this process is also able to help local authorities broker relationships across multiple subscriber organisations will be crucial to whether heat networks continue to be predominantly small and fragmented, or develop as more strategic local energy systems.

\section{Central Government Capital Funding for Heat Networks}

Where $\mathrm{DH}$ schemes have developed over the past decade, funding programmes directed by central government have often been instrumental. The Community Energy Programme (CEP), initiated in 2002 with a budget of $£ 50 \mathrm{~m}$, illustrates aspects of how DH is appraised by government, and challenges in the development of an ongoing development programme. CEP was sponsored by the Department for the Environment, Food and Rural Affairs (Defra). It had social objectives (reducing carbon emissions and fuel poverty), but used a cost-benefit analysis model for appraisal of individual schemes rooted in the financial transactions schemes engaged in (rather than externalised or non-transactional objectives). Future transactional costs and benefits were discounted for comparison with current costs and benefits using a social discount rate of 3.5\% per year (HM Treasury, 2003) which (in theory) weighed equally the preferences of people now and in future. Projects that satisfied the programme's criteria were eligible for up to $40 \%$ capital funding.

The programme imposed demanding timescales on project development, meaning only relatively simple, smaller schemes were able to complete. As heat networks exhibit increasing returns to scale (International Energy Agency, 2005) the performance of the small networks that went ahead under the programme was consequently disappointing. In addition to this, Defra identified difficulties produced by the spike in demand for consultancy and contractor services created by the programme, which exacerbated its poor outcomes (relative to its objectives) by raising prices for these services and lengthening lead times (Hawkey, 2012). In the 2006 review of the UK's Climate Change Programme, the CEP was abruptly ended, with UK Government citing "other programmes that can more cost-effectively deliver carbon savings" (Defra, 2006: 88).

The decision to end the Community Energy Programme echoes Russell's observation both of the narrowing of appraisal metrics, and the role of earlier disappointing schemes in shaping visions and understanding of how DH performs in a UK context. In both programmes Russell examined and the CEP, contextual factors shaping the poor performance of those systems were ignored (including, in the 2006 case, the terms of the funding programme itself, and the broader context of energy systems discussed in the following section). It also illustrates continuity in the 
dependence of local authorities engaged with $\mathrm{DH}$ on central government, and the uncertainties generated for the former by shifts in the position of the latter.

Since the CEP, more grant funding has been made available to local authorities for DH: a £25m 'green stimulus' in 2009 (Homes and Communities Agency, 2011), and funding under climate change obligations imposed on energy companies (DECC, 2012a). Tight timescales for grant spending are still, however, difficult to reconcile with strategic local energy development.

\section{Planning Policy and Building Control}

Powers and guidance issued to local government on spatial planning and building control provide another example of challenging central-local government relationships. Planning guidance issued in England in 2007 required local authorities to develop targets for new development to use renewable and decentralised energy, with funding available to support creation of local evidence bases (Department of Communities and Local Government, 2007). Planning guidance did not, however, indicate how support for decentralised energy should be balanced against other goals set out in the planning system, such as provision of affordable housing or speedy processing of planning applications (Williams, 2010). In spite of this drawback, some local authorities did use the guidance both to create local requirements for new developments (such as housing or commercial buildings) to adopt $\mathrm{DH}$, and to rejuvenate legacy networks on the grounds that new planning guidance opened opportunities to extend these systems (Hawkey, 2013). Following the election of a new UK government in 2010, the planning system underwent a major overhaul through the Localism Act 2011, under which regional planning strategies were abandoned, central government guidance was simplified to remove "top-down" policies (such as those set out around decentralised energy) and local groups were given powers to develop neighbourhood plans within the planning system. Officers from local authorities which had aligned their DH planning approach around planning guidance and support from regional bodies report these reforms undermined their capacity to develop robust local policy with some describing the new arrangements as a 'shipwreck' in workshop discussions (Hawkey, 2013).

Building standards have passed through a parallel evolution, with a 2006 policy to ensure all new homes built after 2016 were net zero carbon. The policy allowed for onsite emissions to be offset by savings elsewhere, with developers investing in 'allowable solutions' including DH networks. However, the scale of investment the mechanism was expected to produce was significantly reduced in 2011 when central government restricted the definition of 'zero carbon' to cover only emissions associated with heating and lighting (Zero Carbon Hub, 2011), and further uncertainty surrounds the mechanism by which funds generated by the policy will be distributed.

Under these changeable conditions, local government officers participating in a DH workshop on central government policy (see Hawkey, 2013) raised the question of whether local government has a 'mandate' to develop heat networks, and what central government's view is as to who is the 'rightful owner of district energy' (e.g. local authorities or commercial developers). Thus in spite of a rhetoric of releasing local government from central control, in relation to district heating this has not led to perceptions of local authority empowerment among officers, due both to authorities' ongoing dependency on inconstant central government policy, and a tendency among local authorities to look 
to central government to sanction their $\mathrm{DH}$ activities.

\section{Energy Policy and the Co-production of Heat and Power}

The nationalised electricity supply industry, structured as a central generating organisation providing bulk supply to regional distribution boards, played a crucial role in Russell's account of the marginalisation of CHP. Privatisation and liberalisation of the sector has resulted in significant restructuring of the industry, now based around six companies integrating generation and retail activities, supplying 99\% of domestic customers (Ofgem, 2008). While the principle of de-integration was not sustained with respect to electricity generation and retail (Thomas, 2006), distribution and transmission networks are separated as regulated monopolies. While two of the six integrated companies do operate distribution networks, they are required to keep these separate from generation and retail activities behind "Chinese Walls". Activities of the companies are overseen by an independent regulator, Ofgem, and European directives play an increasing role in governance of the sector. Thus the range of actors involved in the sector (either as direct participants or in governance) has increased, and monopoly power has been mitigated by a mixture of competition and independent regulation. To what extent has this opened opportunities for CHP and DH?

\section{Participation in Energy Markets}

During both $\mathrm{CHP} / \mathrm{DH}$ programmes, the nationalised electricity supply industry perceived small CHP systems embedded in distribution networks as contrary to its interests in centralised generation, and offered poor terms for connection to the network and low tariffs (Russell, 1993).
The current regulatory split between Distribution Network Operators (DNOs) and generators in principle alleviates this conflict. However, while DNOs formally do not have an interest in generation, the UK regulatory model, a form of pricecap regulation, still creates misalignment between DNO interests and distributed generation. The intended impact of price cap regulation was to drive cost reduction (Bolton \& Foxon, 2011). The nationalised industry had left a legacy of networks with significant capacity margins built in, and DNOs have faced little need to invest in network innovation. Consequently, they have profitably operated by cutting $R \& D$ spending in network development, and have done little to reconfigure networks to better accommodate decentralised generation (for example, through active power management), instead treating proposals to connect generation in a piecemeal fashion, leading to high connection charges (Bolton \& Foxon, 2011). In its 2005 Price Control Review, the regulator introduced financial incentives for DNOs to invest in R\&D and to trial network innovations to connect distributed generation. While $\mathrm{R} \& \mathrm{D}$ spending did increase, only three network innovation projects were undertaken (Bolton \& Foxon, 2011). Distributed generators continue to complain that DNOs impose opaque conditions and high charges for connection (Ofgem, 2011a).

Where CHP operators have connected to the public system, they have found participation in the UK's wholesale market challenging. Credit and administrative requirements are high, and penalties for failing to generate the quantity of electricity forecast can be relatively more severe for CHP operators than for large companies able to respond to imbalances within their own portfolios (Toke \& Fragaki, 2008). Long term planning for CHP developers 
is made challenging by poor visibility of future electricity prices as wholesale market liquidity is low, because wholesale electricity transactions are dominated by self-supply within vertically integrated supplier/generators (Ofgem, 2011b).

Small CHP generators therefore usually avoid the wholesale market. Some sell to a consolidator, an energy supplier which effectively treats a generator's output as negative demand but at tariffs considerably lower than wholesale prices (Toke \& Fragaki, 2008). Sale over a 'private wire' network (i.e. a distributed generator's own network outside the public distribution system) can generate income comparable with retail electricity prices, and exemptions from the electricity generation licensing regime limit costs, albeit while also limiting permissible scale (London Energy Partnership, 2007). Private wire networks also give small generators the advantage of a relatively stable market as users face a barrier to switching suppliers in the form of the cost of a new connection to the public system. However, in 2008 the European Court of Justice ${ }^{1}$ found against this form of supply monopoly, ruling that private wire networks must grant access to third party suppliers to allow subscribers access to competitive markets, undermining the long-term business models for $\mathrm{CHP} / \mathrm{DH}$ systems with private wire. For example, an interviewee from a municipally owned energy services company (ESCo) indicated fears that larger companies would offer 'silly prices' to poach the lucrative customers connected to the ESCo's private wire (office developments, supermarkets, shopping centres, etc.). These market conditions for CHP electricity, therefore, favour more restricted situations where long term agreements for power supply to large users can be brokered. Our research on specific cases in the UK indicates such agreements tend to rely on organisational relationships, for example campus-based CHP/DH systems where heat and power are used by a single organisation such as a university, or municipally-led schemes where electricity can be used by municipal facilities such as leisure centres and schools (e.g. Webb \& Hawkey, 2014).

Several recent regulatory changes and incentive mechanisms have been introduced or are in development to tackle both network access and access to power markets: a new regulatory regime for DNOs (Ofgem, 2010); a mechanism for small generators to use the resources of licensed suppliers who would voluntarily give them access to the retail market, 'License Light' (Ofgem, 2009); proposals to increase wholesale market liquidity (Ofgem, 2012); and proposals to subsidise gas CHP (DECC, 2013). What the outcome of these combined changes will be is difficult to predict, and indeed this difficulty of knowing how what the outcome of interventions and regulatory changes will be is, as Mitchell (2008) argues, a characteristic of the RSP. That outcomes may not cohere with intentions is demonstrated by the failure of the 2005 attempt to incentivise DNOs to accommodate more distributed generation.

\section{Preferences of the Incumbent Energy Companies}

Several of the six dominant energy companies in the UK have small business units focused on CHP and DH. These units undertake a variety of development, construction and operational roles in DH systems, some appearing to invest defensively, others seeking more constructive local engagement. However, the overarching financial models and investment preferences of the incumbents are difficult to reconcile with the locally specific, incremental and social-capital oriented characteristics of much DH development (Hawkey et al., 2013). The 
reorientation of the industry in the wake of liberalisation, away from national systems of energy production, towards international ownership and associated flows of capital and technologies result in preferences for delocalised, scalable, replicable and predictable investment opportunities (Winskel, 2002). The mismatch is particularly stark in terms of investment scale. DH initiatives, limited by the difficulties in coordinating subscribers, rarely exceed around ten million pounds of investment. While there has been some participation among the incumbents in a handful of projects at this scale, they are small in comparison with other energy investments. For example, an officer from one of the Big Six energy companies indicated at practitioner and research workshops that his company would see half a billion pounds as a minimum investment in a scheme.

Analysis of policy documents since 2003 suggests the incumbent companies are resistant to interventions designed to encourage co-generation of heat and power from their large thermal power stations. In 2003, UK government committed to alter the procedures for power station consents, requiring generators to demonstrate they had considered options for heat off-take (DTI, 2003). However, as the distance heat can be transmitted via pipes is limited (by financial, rather than technical constraints, Roberts, 2008), these considerations would only conclude in favour of cogeneration if plant were located close to sites of considerable heat demand. The change to the consent procedures did not require consideration of alternative locations for their plant when appraising CHP opportunities, and consequently were ineffective as developers selected sites too far from demand centres for the option to be viable (DECC, 2009: 96). Early drafts of the 2012 EU Energy Efficiency Directive proposed stronger regulation that new and refurbished thermal generation plant above 20MW be required to operate in CHP mode. In research interviews and discussions, commercial and policy officers indicate that UK industry and government actively resisted this proposal which was eventually watered down to a requirement to conduct a cost/benefit analysis of CHP operation, reducing the estimated energy savings impact of the measure by $70 \%$ from 25 Mtoe to 8 Mtoe (Services of the European Commission, 2012).

\section{Influences on UK Government Energy Policy}

Following the programme to privatise and liberalise the energy sector in the 1990s, UK government did not produce a formal energy policy until 2003. The re-emergence of energy policy, driven by energy security and climate change concerns, was formulated in a White Paper. CHP was set alongside renewables as being central to a vision of future low carbon generation (DTI, 2003), and both forms of generation were exempted from the new Climate Change Levy. DH was also directly supported under the UK's Community Energy Programme described above.

In the $\mathrm{CHP} / \mathrm{DH}$ programmes of the $1940 / 50$ s and $1970 / 80$ s, CHP struggled to find a place in an electricity system not designed for it (Russell, 1993). Parallel difficulties were acknowledged in the 2003 White Paper: "nationwide and local electricity grids, metering systems and regulatory arrangements [...] were created for a world of large-scale, centralised power stations." It argued that these would all need to be restructured to accommodate renewable and decentralised energy (DTI, 2003: para.1.40). The paper identified several barriers to greater deployment of CHP and DH, namely terms of access to distribution networks, difficulties 
participating in wholesale markets, and the failure of the planning system to direct new power stations to be located sufficiently close to areas of high heat demand that large scale heat off-take would be possible.

As discussed above, a decade later these issues still challenge widespread development of DH and CHP. While the 2003 White Paper envisaged an energy system re-oriented to distributed generation, its successor in 2007 was more ambivalent, seeing decentralised generation as "a complement rather than an alternative to centralised generation" (DTI, 2007: para.3.8). By the 2009 Energy White Paper, mention of decentralised generation and its challenges was completely dropped (DECC, 2009). When decentralised energy has appeared in recent policy documents, its role has been presented as marginal: "the Government does not believe that decentralised and community energy systems are likely to lead to significant replacement of larger-scale infrastructure" (DECC, 2011b: para.3.3.29).

A number of factors may be adduced to explain this return to decentralised energy being considered as adjunct rather than alternative to the centralised system, including the forms of analysis used in policy development, the influence of incumbent interests on policy visions, and divisions within government between producer and consumer oriented policy making.

Russell (1993) argued that appraisal methods disguised organisational interests in apparently technical debates, pointing particularly to the way $\mathrm{CHP}$ and $\mathrm{DH}$ were appraised by the nationalised electricity industry. Computational models informing policy are predominantly commissioned by government from either commercial consultancies or academic institutions, suggesting the interests of electricity generators do not have the same direct influence over selection of appraisal methods. However, UK policy has reoriented towards visions of centralised energy systems, and Rogers-Hayden et al. (2011) argue that industry interests have played a crucial role in shaping those visions. They describe how energy security and climate change discourses were reshaped between 2003 and 2005 by an intensive lobbying campaign by nuclear power interests. Climate change shifted from being a "symptom of unsustainability" to an "environmental issue", and energy security shifted from a "lack of diversity" to a "gas-gap". Both changes marginalising arguments in favour of decentralised energy and supporting visions of electrification (of heat and transport) which emerged as core solutions to energy problems (e.g. UK Committee on Climate Change, 2008).

Mitchell (2008) argues that the UK government was receptive to this reframing in part because a centralised approach is more familiar and hence more attractive: appearing to require less intervention in the daily lives of millions of UK citizens; implying continuity in the retail market and supplier business models; and requiring construction of a small number of large plants rather than a large number of smaller interventions. This orientation to producer interests was, before 2008, reflected in the departmental structure of UK government, with the Department for Trade and Industry assuming responsibility for production side policy, and the Department for Environment, Food and Rural Affairs responsible for climate change and energy consumption policies areas such as fuel poverty. The Department of Energy and Climate Change (DECC), created in 2008, was designed to overcome these divisions, but after five years the internal structure of DECC maintains a high level division between production and consumption (DECC, 2012b), officers acknowledge in 
research interviews that this structural division is reflected in the work of the department, and outsiders complain that these policy silos lead to outcomes which frustrate development of $\mathrm{CHP}$ and $\mathrm{DH}$ (Meeks, 2013).

\section{Conclusions}

In a striking formulation, Russell (1993: 50) concluded that "some basic features of our social and economic organisation mean it is intrinsically incapable of promoting efficient use of resources." The evidence reviewed above indicates that, while there have been many changes to the social and economic organisation of the UK, particularly attempts to disperse decision making away from central government in both energy and local government, key features underpinning the frustration of previous attempts to develop widespread $\mathrm{CHP} / \mathrm{DH}$ programmes remain and challenge the prospects for contemporary development. In the electricity sector, while the UK model of liberalisation and privatisation has ended the monopoly of the nationalised industry, the new regulatory structures and organisational interests are aligned around the centralised system of generation which they inherited. This alignment contributes to the marginal economics of CHP through connection terms and tariffs available to CHP operators. In local government, while authorities have greater formal freedom to develop DH schemes, limits to their capacity and ongoing dependence on changeable central government policy mean projects are developed in unusual circumstances and are often small, fragmented systems rather than the comprehensive strategic networks able to achieve economies of scale and scope.

In addition to these broad systemic continuities, some of the detailed reasons for the marginalisation of CHP and DH identified by Russell have contemporary parallels. While a range of social goals are often acknowledged in policy documents, appraisal of support programmes and future scenarios (through modelling) adopt narrow financial criteria. Schemes which do manage to find a place in the interstices of unfavourable energy and local governance conditions perform poorly against such criteria, contributing to the marginalisation of $\mathrm{DH}$ and CHP from visions of future energy systems which can worsen the already unfavourable conditions (as, for example, happened with the decision to withdraw funding under the CEP).

While the retreat of central government from active planning was a component of the failure of both national programmes Russell studied, the inappropriateness of government planning (as opposed to competitive market allocation) is virtually axiomatic in contemporary policy development under the RSP, including in relation to heat infrastructure (e.g. DECC, 2011c: para.25; DECC, 2013: para.3.55). As Mitchell (2008) argues, government determination to maintain technology neutrality and market efficiency leads to ineffective policies, whose impacts are difficult to predict, and which can achieve change only slowly. While central government recognised systematic barriers to deployment of decentralised energy a decade ago (DTI, 2003), policy responses have not managed to overcome these issues, suggesting Russell and Williams' (2002a: 145) concerns that technology policies could "resign [themselves] to minor tinkering with agendas and directions of development set by powerful interests" were well founded.

The division in the energy sector between producer interests and consumer interests (as meditated by local government) is still present in the UK, both 
in the autonomy of the companies which dominate the production and supply of energy from local government, and in the enduring split between production and consumption issues in energy policy. However, there are some countervailing pressures in the UK which merit further attention for understanding the prospects for district energy. Devolved government (in Scotland, Wales, Northern Ireland and London) created at the end of the 1990s has responsibility for local government, and restricted competence in governance of the centralised energy system. Under these conditions, support for local government in developing $\mathrm{DH}$ networks is one way devolved government can intervene in energy issues confronting its domain, and London in particular has pursued relatively clear decentralised energy policies (Greater London Authority, 2008, 2009; Williams, 2010). Tensions between the form of market liberalisation in the UK and the objectives of energy security, affordability and climate change mitigation are increasingly recognised in UK energy policy and underpin current efforts to reform the electricity market (DECC, 2011a). The UK opposition Labour Party announced in 2013 its intention, should it form the next government, to freeze energy prices for twenty months during which it would 'reset' the energy market, though details remain vague (Milliband, 2013). The UK may therefore be entering a new phase of upheaval in the energy sector, though it remains to be seen whether this creates conditions which mitigate or resolve the tensions between producer and consumer interests which Russell argued lay behind much of the marginalisation of CHP and DH.

\section{Acknowledgements}

The research underpinning this paper is part of the RC-UK research project Heat And The City: Comparing the Trajectory of Sustainable Heat and Energy Conservation in Municipal Communities in which Stewart Russell was a co-investigator at the time of his death. I acknowledge the contributions to the research of other colleagues and team members: Richard Bellingham (University of Strathclyde), Andy Kerr, Heather Lovell, David McCrone, Jan Webb and Mark Winskel (University of Edinburgh). We are grateful for research funding from the UK Research Councils' Energy Programme, Grant Ref: RES-628-25-0052.

\section{References}

Bolton, R. \& T.J. Foxon (2011) 'Governing Infrastructure Networks For A Low Carbon Economy: Co-Evolution Of Technologies And Institutions In UK Electricity Distribution Networks,' Competition and Regulation in Network Industries 12(1): 2-27.

Bulkeley, H. \& K. Kern (2006) 'Local Government and the Governing of Climate Change in Germany and the UK', Urban Studies 43(12): 2237 - 2259.

DECC (2009) The UK Low Carbon Transition Plan [Online]. Available from: http://www.decc.gov.uk/en/content/ cms/publications/lc_trans_plan/lc_ trans_plan.aspx [Accessed: 2 October 2009].

DECC (2011a) Electricity Market Reform White Paper [Online]. Available from: http://www.decc.gov.uk/en/content/ cms/legislation/white_papers/emr_ wp_2011/emr_wp_2011.aspx [Accessed: 27 July 2011].

DECC (2011b) Overarching national policy statement for energy (EN-1) [Online]. Available from: https://whitehall-admin. 
production.alphagov.co.uk/government/ uploads/system/uploads/attachment_ data/file/37046/1938-overarching-npsfor-energy-en 1.pdf [Accessed: 30 January 2013].

DECC (2011c) The carbon plan: Delivering our low carbon future [Online]. Available from: http://www.decc.gov. uk/en/content/cms/tackling/carbon plan/carbon_plan.aspx [Accessed: 7 December 2011].

DECC (2012a) The Green Deal and Energy Company Obligation: Government Response to the November 2011 Consultation [Online]. Available from: http://www.decc.gov.uk/en/content/ cms/consultations/green_deal/green_ deal.aspx [Accessed: 22 August 2012].

DECC (2012b) DECC corporate organogram [Online]. Available from: https://www.gov.uk/government/ uploads/system/uploads/attachment_ data/file/66114/2721-decc-corporateorganogram.pdf.

DECC (2013) The future of heating: Meeting the challenge [Online]. Available from: https://www.gov.uk/government/ publications/the-future-of-heatingmeeting-the-challenge [Accessed: 22 April 2013].

Defra (2006) Climate Change: The UK Programme 2006. Tomorrow's Climate, Today's Challenge [Online]. Available from: http://www.official-documents. gov.uk/document/cm67/6764/6764.pdf [Accessed: 30 September 2013].

Department of Communities and Local Government (2007) Planning Policy Statement: Planning and Climate Change. Supplement to Planning Policy Statement 1 [Online]. Available from: http://www.communities.gov.uk/ publications/planningandbuilding/ ppsclimatechange [Accessed: 14 December 2011].
DTI (2003) Our energy future [Online]. Available from: http://webarchive. nationalarchives.gov.uk/+/http:// www.berr.gov.uk/files/file10719.pdf [Accessed: 25 February 2013].

DTI (2007) Meeting the Energy Challenge: A White Paper on Energy [Online]. Available from: http://www.berr.gov. uk/files/file39387.pdf [Accessed: 16 February 2010].

Ericson, K. (2009) 'Introduction and development of the Swedish district heating systems: Critical factors and lessons learned, RES-H Policy project working paper [Online]. Available from: http://www.res-h-policy.eu/downloads/ Swedish_district_heating_case-study_ (D5)_final.pdf [Accessed: 8 November 2010].

Fudge, S., M. Peters, Y. Mulugetta \& T. Jackson (2011) 'Paradigms, Policy and Governance: The Politics of Energy Regulation in the UK Post-2000, Environmental Policy and Governance 21(4): 291-302.

Graham, S. \& S., Marvin (2001) Splintering Urbanism: Networked Infrastructures, Technological Mobilities and the Urban Condition (London: Routledge).

Greater London Authority (2008) The London Plan: Spatial Development Strategy for Greater London. Consolidated with changes since 2004 [Online]. Available from: http://www. london.gov.uk/thelondonplan/docs/ londonplan08.pdf [Accessed: 28 October 2014].

Greater London Authority (2009) Powering ahead: delivering low carbon energy for London [Online]. Available from: http:// www.london.gov.uk/sites/default/files/ powering-ahead141009.pdf [Accessed: 2 August 2011].

Grohnheit, P. \& B. O. G. Mortensen (2003) 'Competition in the market for space heating. District heating as the 
infrastructure for competition among fuels and technologies,' Energy Policy 31(9), 817-826.

Hawkey, D. (2012) 'District heating in the UK: A Technological Innovation Systems analysis,' Environmental Innovation and Societal Transitions 5: 19-32.

Hawkey, D. (2013) District Heating Policy Options in the UK: Workshop report [Online]. Available from: h t t p : / / w w w. heat a nd thecity. org.uk/_ d a t a / a s s e t s / p d f file/0006/102003/VanguardsNetworkHeatPolicyOptionsWorkshopReport.pdf [Accessed: 8 October 2013].

Hawkey, D., Webb, J. \& M. Winskel (2013) 'Organisation and governance of urban energy systems: district heating and cooling in the UK', Journal of Cleaner Production 50: 22-31.

Hekkert, M., Harmsen, R. \& A. de Jong (2007) 'Explaining the rapid diffusion of Dutch cogeneration by innovation system functioning, Energy Policy 35 (9): 4677-4687.

Helm, D. (2004) Energy, the state, and the market: British energy policy since 1979 (Oxford: Oxford University Press).

Helm, D. (2005) 'The Assessment: The New Energy Paradigm, Oxford Review of Economic Policy 21(1): 1-18.

Hills, J. (2012) Getting the measure of fuel poverty: final report of the fuel poverty review [Online]. Available from: https:// www.gov.uk/government/publications/ final-report-of-the-fuel-poverty-review [Accessed: 5 November 2014].

HM Treasury (2003) Green Book, Appraisal and Evaluation in Central Government [Online] Available from: https://www. gov.uk/government/uploads/system/ uploads/attachment_data/file/220541/ green_book_complete.pdf [Accessed 28 October 2014].
Homes and Communities Agency (2011) District Heating Good Practice Guide: Learning from the Low Carbon Infrastructure Fund [Online]. Available from: http://www. homesandcommunities.co.uk/districtheating-good-practice-learning-lowcarbon-infrastructure-fund [Accessed: 3 August 2011].

International Energy Agency (2005) A Comparison of distributed $\mathrm{CHP} / \mathrm{DH}$ with large-scale CHP/DH (International Energy Agency District Heating and Cooling Research Programme report 8DHC-05.03).

International Energy Agency (2009) Cogeneration and district energy: Sustainable energy technologies for today... and tomorrow [Online]. Available from: http://www.iea.org/ files/CHPbrochure09.pdf [Accessed: 24 November 2010].

King, M. \& R. Shaw (2010) Community energy: planning, development and delivery [Online]. Available from: http:// www.chpa.co.uk/media/28c4e605/ Comm_Energy_PlanDevDel.pdf [Accessed: 24 November 2010].

Leach, R. \& J. Percy-Smith (2001) Local governance in Britain (Hampshire: Palgrave).

Lehtonen, M. \& S. Nye (2009) 'History of electricity network control and distributed generation in the UK and Western Denmark', Energy Policy 37 (6): 2338-2345.

London Energy Partnership (2007) Making ESCos Work: Guidance and Advice on Setting Up \& Delivering an ESCo [Online]. Available from: http://www. lep.org.uk/uploads/lep_making_escos_ work.pdf [Accessed: 27 October 2010]. 
Lovell, H., McCrone, D., Winskel, M., Webb, J., Kerr, A., Bellingham, R. \& D. Hawkey (2011) Heat and the City workshop on Municipal Leadership and Organisation for District Energy: Workshop report [Online]. Available from: http://www.heatandthecity.org. uk/our_work/workshop_-_leadership_ and_organisation_for_district_energy [Accessed: 22 November 2011].

Martin, S. (2011) 'What is Localism, and does it matter?', Paper presented to the Commonwealth Local Government Forum Research Colloquium: Sustainable local governance for prosperous communities. [Online]. Available from: http://www.clgc2011. org / userfiles / 7 / files / S teve\% 20 Martin\% $20-\% 20 \mathrm{Wh}$ at $\% 20$ is $\% 20$ localism $\% 20$ and $\% 20$ does $\% 20$ it $\% 20$ matter.doc.pdf [Accessed: 20 October 2011].

Meeks, G. (2013) Oral evidence on the Gas Generation Strategy, Wednesday 13 February 2013 [Online]. Available from: http://www.publications.parliament. $\mathrm{uk} / \mathrm{pa} / \mathrm{cm} 201213 / \mathrm{cmselect/cmenergy/}$ uc987/uc98701.htm [Accessed: 28 February 2013].

Milliband, E. (2013) Freeze that bill [Online]. Available from: http://www. labour.org.uk/freeze-that-bill [Accessed: 8 October 2013].

Mitchell, C. (2008) The Political Economy of Sustainable Energy (Hampshire: Palgrave Macmillan).

Moran, M. (2003) The British regulatory state: high modernism and hyperinnovation (Oxford: Oxford University Press).

Nutley, S., J. Downe, S. Martin \& C. Grace (2012) 'Policy transfer and convergence within the UK: the case of local government performance improvement regimes', Policy \& Politics 40 (2): 193-209.
Ofgem (2008) Energy supply probe - Initial findings [Online] Available from: http:// www.ofgem.gov.uk/Markets/RetMkts/ ensuppro/Pages/Energysupplyprobe. aspx [Accessed: 27 May 2011].

Ofgem (2009) Distributed Energy - Final Proposals and Statutory Notice for Electricity Supply Licence Modification [Online]. Available from: http:// www.ofgem.gov.uk/Sustainability/ Environment/Policy/SmallrGens/ DistEng/Documents 1 / DE_Final_ Proposals.pdf [Accessed: 9 August 2011]. Ofgem (2010) RIIO - a new way to regulate energy networks [Online]. Available from: http://www.ofgem.gov.uk/ Media/FactSheets / Documents 1/ re-wiringbritainfs.pdf [Accessed: 27 February 2013].

Ofgem (2011a) High Level Summary of DG Forum Responses [Online]. Available from: http://www.ofgem. gov.uk/Networks/ElecDist/Policy/ DistGen/Documents1/high\%20level\%20 summary\%20 of\%20DG\%20Forum published.pdf.

Ofgem (2011b) The Retail Market Review Findings and initial proposals [Online]. Available from: http://www.ofgem.gov. uk/Markets/RetMkts/rmr/Documents 1/ RMR_FINAL.pdf [Accessed: 28 February 2013].

Ofgem (2012) Retail Market Review: Intervention to enhance liquidity in the GB power market [Online]. Available from: http://www.ofgem.gov.uk/ Markets/RetMkts/rmr/Documents 1/ Liquidity\% 20 Feb\% 20 Condoc.pdf [Accessed: 27 February 2013].

Palmer, J. \& I. Cooper (2011) Great Britain's Housing Energy Fact File [Online]. Available from: https://www.gov.uk/ government/uploads/system/uploads/ attachment_data/file/48195/3224-greatbritains-housing-energy-fact-file-2011. pdf [Accessed: 27 February 2013]. 
Raven, R. \& G. Verbong (2007) 'MultiRegime Interactions in the Dutch Energy Sector: The Case of Combined Heat and Power Technologies in the Netherlands 1970-2000', Technology Analysis \& Strategic Management 19(4): 491-507.

Roberts, S. (2008) 'Infrastructure challenges for the built environment', Energy Policy 36(12): 4563-4567.

Rogers-Hayden, T., Hatton, F. \& I. Lorenzoni (2011) “Energy security' and 'climate change': Constructing UK energy discursive realities', Global Environmental Change 21(1): 134-142.

Rotheray, T. (2011) 'Onsite generation and demand response - the role of the EMR', Presentation to District Energy Vanguards Workshop on Leadership for District Energy [Online]. Available from: http://www.heatandthecity.org.uk/ data/assets/pdf_file/0010/71758/7_-_ Tim_Rotheray_-_Onside_generation_ and_demand_response_the_role_of_ the_EMR.pdf [Accessed: 14 January 2012].

Russell, S. (1993) 'Writing Energy History: Explaining the Neglect of CHP/DH in Britain, British Journal for the History of Science 26(1): 33-54.

Russell, S. (1994) 'Combined Heat and Power in Britain', in Hard, M. \& S. Olson (eds), The Combined Generation of Heat and Power in Great Britain and the Netherlands: Histories of Success and Failure (Stockholm: Närings- och Teknikutvecklingsverket / Swedish National Board for Industrial and Technical Development).

Russell, S. (1996) 'At the Margin: British Electricity Generation after Nationalisation and Privatisation, and the Fortunes of Combined Heat and Power', Paper presented to SHOT '96: conference of the Society for the History of Technology, London.
Russell, S. \& R. Williams (2002a) 'Concepts, Spaces and Tools for Action? Exploring the Policy Potential of the Social Shaping Perspective', in Sørensen, K. \& R. Williams (eds), Shaping Technology, Guiding Policy: Concepts, Spaces and Tools (Cheltenham: Edward Elgar): 133154.

Russell, S. \& R. Williams (2002b) 'Social Shaping of Technology: Frameworks, Findings and Implications for Policy with Glossary of Social Shaping Concepts', in Sørensen, K. \& R. Williams (eds), Shaping technology, guiding policy: Concepts, spaces and tools (Cheltenham: Edward Elgar): 37-131.

Rutherford, J. (2008) 'Unbundling Stockholm: The networks, planning and social welfare nexus beyond the unitary city', Geoforum 39(6): 1871-1883.

Services of the European Commission (2012) Non-paper on the Energy Efficiency Directive presented to the Informal Energy Council [Online]. Available from: http://ec.europa.eu/ energy/efficiency/eed/doc/20120424_ energy_council_non_paper_efficiency_ en.pdf [Accessed: 28 February 2013].

Summerton, J. (1992) District heating comes to town: The social shaping of an energy system (Linköping: Linköping University).

Thomas, S. (2006) 'The British Model in Britain: Failing slowly', Energy Policy 34 (5): 583-600.

Toke, D. \& A. Fragaki (2008) 'Do liberalised electricity markets help or hinder CHP and district heating? The case of the UK', Energy Policy 36(4): 1448-1456.

UK Committee on Climate Change (2008) Building a low-carbon economy - the UK's contribution to tackling climate change [Online]. Available from: http:// www.theccc.org.uk/reports/buildinga-low-carbon-economy [Accessed: 7 December 2011]. 
Webb, J. \& D. J. C., Hawkey (2014) Aberdeen Heat and Power Ltd - draft Case Study for DH Delivery Structures Guidance, Scottish Futures Trust, 2014 [Online]. Available from http://www. heatandthecity.org.uk/_data/assets/ pdf_file/0006/158739/SFT_DH_Case_ studies_AHP.pdf [Accessed: 28 October 2014].

Weber, K. (2003) 'Transforming Large Socio-technical Systems towards Sustainability: On the Role of Users and Future Visions for the Uptake of City Logistics and Combined Heat and Power Generation', Innovation: The European Journal of Social Science Research 16(2), 155-175.

Williams, J. (2010) 'The deployment of decentralised energy systems as part of the housing growth programme in the UK', Energy Policy 38(12): 7604-7613.

Wilson, D. \& C. Game (2002) Local Government in the United Kingdom. 3rd edition. (Hampshire: Palgrave Macmillan).
Winskel, M. (2002) 'When Systems are Overthrown: The 'Dash for Gas' in the British Electricity Supply Industry', Social Studies of Science 32(4): 563-598.

Zero Carbon Hub (2011) Allowable solutions for tomorrow's new homes: towards a workable framework. [Online]. Available from: http://www.zerocarbonhub.org/ definition.aspx?page $=9$ [Accessed: 12 July 2011].

David J. C. Hawkey

Institute of Governance, School of Social and Political Science, University of Edinburgh Chisholm House, High School Yards, Edinburgh EH1 1LZ, UK.

Dave.Hawkey@ed.ac.uk

\section{Notes}

1 Case C-439/06: Energy Management Proceedings Citiworks AG 